\title{
Problems of Bacteriological Pollution in Water Wells in Wadi Hadramout Water Project
}

\author{
*Salem M. Bin Qadhi, "Saeed Y. Bashir and Taha O. Assaggaf \\ ${ }^{*}$ Department of Mechanical Engineering, Faculty of Engineering, University of \\ Aden, Aden Republic of Yemen, "National Water and Sanitation Authority, Wadi \\ Hadramout, Seiyun Republic of Yemen.
}

مشكلات التلوث البليولوجي فميل البارفي مشروع وامى حضرموت

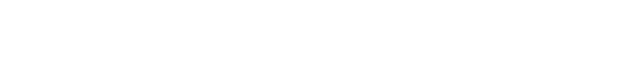

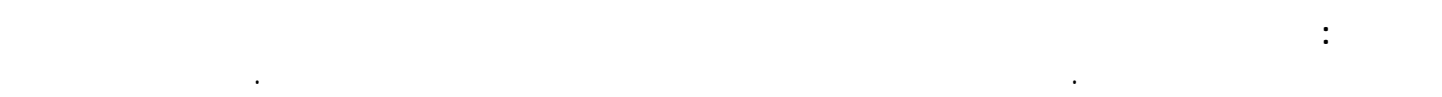

\begin{abstract}
This paper presents an existing problem of drinking water pollution for a small project and one of the model projects of drinking water in Yemen, designed to save and preserve good quality water for the present and future generations in the area. The paper gives the details of the project and explains the problem of bacteriological pollution and the steps undertaken to solve the problem. Some of the results for short-term solutions and recommendation for the long-term solutions are also given.
\end{abstract}

KEYWORDS: Collapsible Soils, Identification, Laboratory Tests, Field Tests, Stabilization, Foundation Design.

\section{Introduction}

Yemen is a developing country having a population of about 17 million depending mainly on ground water for drinking. Yemen is suffering from a shortage of water and has witnessed a number of drinking water crises in some large cities. This forced the concerned authorities to give priority to drinking water projects in the country. Among leading drinking water projects carried out in Yemen, is the Wadi Hadramout Drinking Water Project which was studied, designed and carried out by international consultants and contractors.

Wadi Hadramout Water Supply Project includes Seiyun, Shibam, Al-Qatin and recently Tarim water supply. The project under study is Seiyun Drinking Water Project which is part of Wadi Hadramout Water Project. Seiyun is the capital of Wadi Hadramout and is one of the historical cities in Yemen. It is situated at latitude $15.58^{\circ}$ and $48.47^{\circ}$ longitude, $20 \mathrm{~km}$ from the famous historical town of Shibam and $25 \mathrm{~km}$ from Tarim. Seiyun is gaining importance since it is located near the oilfields of Masila and witnessing development in different fields. Seiyun Drinking Water Project was established in 1985 to replace 14 private projects established sometime in 1960. Presently, Seiyun Drinking Water Supply covers Seiyun, Al-Hawtah and 30 villages with a population of around 84,000. The estimated number of service connections by mid 1997 is 12,000. Seiyun Drinking Water Project (Table 1) consists of the following:

- The source of drinking water for the project is the deep acquifer ground water where the shallow aquifer water being used for agriculture, gardening and for the use in mosques. 
- 7 boreholes with submersible pumps which abstracts an average of $15,120 \mathrm{~m}^{3} /$ day (Dar AlHandasah). Two boreholes have been drilled but not yet equipped with pumps (Kingdom of Netherlands).

- One main reservoir of $2,700 \mathrm{~m}^{3}$ in Seiyun and 7 small reservoirs distributed in the villages having capacities of 100-200 $\mathrm{m}^{3}$ each.

- A standby generator of $400 \mathrm{kVA}$.

- Chlorine treatment plant.

- Main network consists of ductile iron, $\phi 100-400 \mathrm{~mm}$ with a total length of $85 \mathrm{~km}$ and branch distribution network consists of galvanized iron pipes with a currently estimated length of more than $200 \mathrm{~km}$.

Table 1: Summary of Seiyun drinking water project (Dar Al-Handasah, Kingdom of Netherlands and NWSA-Wadi Hadramout branch).

\begin{tabular}{|c|c|}
\hline ITEM & SPECIFICATIONS \\
\hline 1. System configuration & \\
\hline Number of water wells & $\begin{array}{l}9 \text { of } 150-200 \mathrm{~m} \text { depth and of } 35-45 \mathrm{~m} \text { water } \\
\text { depth }\end{array}$ \\
\hline Treatment type & Chlorine \\
\hline Number of storage tanks & 8 \\
\hline Storage capacity $\left(\mathrm{m}^{3}\right)$ & 3700 \\
\hline Number of booster pumps & 1 at $\mathrm{Al}$ Hawta \\
\hline Length of network (km) & 235 \\
\hline Connections & 12,000 \\
\hline 2. Implementation arrangements & \\
\hline Years of design and construction & 1984-1988 \\
\hline Funding agency & Arab Bank and IDA \\
\hline 3. Details of wells: & \\
\hline Number in use & $7,5 \mathrm{~m}$, cemented \\
\hline Number not operational (and reasons) & $2,50 \mathrm{~m}$, cemented (not equipped) \\
\hline $\begin{array}{l}\text { Maximum water production } \\
\text { capacity }\left(\mathrm{m}^{3} / \text { day }\right) \text { of wells in use }\end{array}$ & 15,120 \\
\hline 4. Supply Capacity and Consumption: & \\
\hline Uncounted for water(\%) & 37 \\
\hline Demand of existing connections met $(\%)$ & 89 \\
\hline
\end{tabular}

\section{Urban Development Problem of Bactoriological Pollution}

Yemen's population growth rate is $3.1 \%$. Due to the problem of population increase like other cities and urban areas in the world, Seiyun town is facing urban development and population growth faster than that in other neighbouring towns and villages with the attraction mainly being the presence of economic administrative activities.

Seiyun is divided into four sectors and until recently, the expansion is mainly occurring in the south of the town where the majority of land belongs to the state. Due to several factors and reasons the new housing development extended to wellfield. This urban housing development started growing closer to the wellfield in 1992 and is forming a threat to the extension plans of Seiyun wellfield and increased the risk of pollution of underground water due to the use of soak pits as a draining system for more than 1500 houses of the new housing scheme (Dar AlHandasah, Kingdom of Netherlands and M.G. Ondrus).

Recent studies and analysis revealed that there is bacteriological water pollution in some of the water wells existing in the new housing development next to the wellfield area. This problem has been considered by the water authorities management and a number of actions have been taken with the help of local and international funding agencies and consulting experts. Efforts are being 
made side by side to tackle this problem in short-term and long-term measures and are being implemented.

\section{Problem Identification}

We aim to study the protection of the wellfield of Seiyun water source of phase I of the project consisting of 8 boreholes (1985-1995) and phase II originally planned for 1995-2010, where the number of boreholes of the wellfield is to be increased from 9 to 12 and developing a second wellfield.

The problem started when residential units were developed some $150 \mathrm{~m}$ downstream of the Phase (1) wellfield. National Water and Sanitation Authority (NWSA), Seiyun Branch, has imposed on these developments the replacement of the percolation pits by watertight septic tanks.

Regular water analysis is carried out by NWSA-Seiyun branch. Average chemical analysis of water for the year 1999 for the seven boreholes and for borehole No.4 for seven years showed that the water quality is still within the acceptable standards for domestic use for all boreholes as shown in Tables 2A and 2B (Dar Al-Handasah).

Table 2(A): Average chemical analysis results of water for boreholes 1-7 taken at NWSA Laboratory-Wadi Hadramout-Seiyun Branch-taken on 5/3/1999(NWSA-Wadi Hadramout branch).

\begin{tabular}{|c|c|c|c|}
\hline Characteristics & $\begin{array}{l}\text { Average Result Of Analysis For } \\
\text { Boreholes 1-7 For Year } 1999\end{array}$ & $\begin{array}{l}\text { WHO } \\
\text { Guidelines }\end{array}$ & Unit \\
\hline Temperature & 26.7 & & ${ }^{\circ} \mathrm{C}$ \\
\hline Color & 0.0 & 15 & Units \\
\hline Turbidity & 0.0 & 5 & F.T.U \\
\hline PH value & 7.7 & $6.5-8.5$ & Units \\
\hline Conductivity & 827 & & $\mathrm{~S} / \mathrm{cm}$ \\
\hline T. Dissolved Solids & 529 & 1000 & $\mathrm{mg} / \mathrm{l}$ \\
\hline T. Alkalinity as $\mathrm{CaCO}_{3}$ & 240 & & $\mathrm{mg} / \mathrm{l}$ \\
\hline T. Hardness as $\mathrm{Ca} \mathrm{CO}_{3}$ & 332 & 500 & $\mathrm{mg} / \mathrm{l}$ \\
\hline $\begin{array}{l}\text { Calcium Hardness as } \\
\mathrm{Ca} \mathrm{CO}_{3}\end{array}$ & 188 & & $\mathrm{mg} / \mathrm{l}$ \\
\hline Mg Hardness & 144 & & $\mathrm{mg} / \mathrm{l}$ \\
\hline $\begin{array}{l}\text { Non Carbonate } \\
\text { Hardness as } \mathrm{CaCO}_{3}\end{array}$ & 92 & & $\mathrm{mg} / \mathrm{l}$ \\
\hline Bicarbonate $\mathrm{HCO}_{3}$ & 292.8 & & $\mathrm{mg} / \mathrm{l}$ \\
\hline Calcium $\mathrm{Ca}^{++}$ & 75.2 & & $\mathrm{mg} / \mathrm{l}$ \\
\hline Magnesium Mg & 39.5 & & $\mathrm{mg} / \mathrm{l}$ \\
\hline Chloride $\mathrm{Cl}^{-}$ & 82 & 250 & $\mathrm{mg} / \mathrm{l}$ \\
\hline Sulphate $\mathrm{SO}_{4}$ & 85 & 400 & $\mathrm{mg} / \mathrm{l}$ \\
\hline Nitrate $\mathrm{NO}_{3}$ & 3 & 45 & $\mathrm{mg} / \mathrm{l}$ \\
\hline Nitrite $\mathrm{NO}_{2}$ & 0.003 & 0.1 & $\mathrm{mg} / \mathrm{l}$ \\
\hline Sodium $\mathrm{Na}^{+}$ & 52.7 & 200 & $\mathrm{mg} / \mathrm{l}$ \\
\hline Fluoride F & 0.0 & 1.5 & $\mathrm{mg} / \mathrm{l}$ \\
\hline Iron $\mathrm{Fe}$ & 0.01 & 0.3 & $\mathrm{mg} / 1$ \\
\hline Manganese $\mathrm{Mn}^{+}$ & 0.0 & 0.1 & $\mathrm{mg} / \mathrm{l}$ \\
\hline
\end{tabular}

Bacteriological examinations of water showed that the water quality is acceptable and within the acceptable standards till the year 1997 (NWSA-Wadi Hadramout Branch). Recent analysis during the period mid-1997 and thereafter showed that some of the boreholes are contaminated by non- 
fecal coliforms (Dar Al-Handasah and M.G. Ondrus). Analysis for the seven boreholes in use is given in Table 3.

Table 2(B): Chemical analysis results of water borehole No.4 for different years taken at NWSA Laboratory-Wadi Hadramout - Seiyun Branch (NWSA-Wadi Hadramout Branch).

\begin{tabular}{|c|c|c|c|c|c|c|c|c|c|}
\hline \multirow{2}{*}{ Characteristic } & \multicolumn{7}{|c|}{ Result of Analysis } & \multicolumn{2}{|c|}{ WHO GuideLines } \\
\hline & 1986 & 1993 & 1994 & 1995 & 1996 & 1997 & 1998 & WHO & Unit \\
\hline Temperature & 25 & 31 & 24 & 28 & 29 & 26 & 27 & & ${ }^{\circ} \mathrm{C}$ \\
\hline Color & 3 & 0.0 & 0.0 & 0.0 & 0.0 & 1 & 5 & 15 & Units \\
\hline Turbidity & 2 & 0.0 & 0.0 & 0.0 & 0.0 & 0.0 & 0.0 & 5 & F.T.U \\
\hline $\mathrm{pH}$ value & 7.8 & 7.9 & 7.8 & 7.8 & 7.9 & 7.9 & 7.9 & $\begin{array}{l}6.5- \\
8.5\end{array}$ & Units \\
\hline Conductivity & 755 & 732 & 723 & 780 & 783 & 768 & 770 & & $\mu \mathrm{S} / \mathrm{cm}$ \\
\hline T. Dissolved Solids & 588 & 768 & 462 & 480 & 481 & 491 & 492 & 1000 & $\mathrm{mg} / \mathrm{l}$ \\
\hline $\begin{array}{l}\text { T. Alkalinity as } \\
\mathrm{CaCO}_{3}\end{array}$ & 201 & 220 & 216 & 208 & 218 & 230 & 224 & & $\mathrm{mg} / \mathrm{l}$ \\
\hline $\begin{array}{l}\text { T. Hardness as } \mathrm{Ca} \\
\mathrm{CO}_{3}\end{array}$ & 295 & 294 & 290 & 300 & 288 & 300 & 306 & 500 & $\mathrm{mg} / 1$ \\
\hline $\begin{array}{l}\text { Calcium Hardness as } \\
\mathrm{Ca} \mathrm{CO}_{3}\end{array}$ & 160 & 200 & 198 & 202 & 206 & 210 & 212 & & $\mathrm{mg} / 1$ \\
\hline Mg Hardness & 135 & 94 & 92 & 98 & 82 & 90 & 94 & & $\mathrm{mg} / 1$ \\
\hline $\begin{array}{l}\text { Non-Carbonate } \\
\text { Hardness as } \mathrm{Ca} \mathrm{CO}_{3}\end{array}$ & -- & -- & -- & -- & -- & -- & 82 & & $\mathrm{mg} / 1$ \\
\hline Bicarbonate $\mathrm{HCO}_{3}$ & 245.2 & 268.4 & 263 & 254 & 266 & 230 & 273.2 & & $\mathrm{mg} / 1$ \\
\hline Calcium $\mathrm{Ca}++$ & 64 & 80 & 79 & 80.8 & 82.4 & 70 & 84.8 & & $\mathrm{mg} / 1$ \\
\hline Magnesium Mg & 32.8 & 22.56 & 22 & 24 & 19.6 & 21.6 & 22.5 & & $\mathrm{mg} / 1$ \\
\hline Chloride $\mathrm{Cl}^{-}$ & 87.3 & 71 & 74 & 76 & 75.6 & 78 & 78 & 250 & $\mathrm{mg} / 1$ \\
\hline Sulphate $\mathrm{SO}_{4}$ & 84 & 30 & 38 & 36 & 42 & 48 & 78 & 400 & $\mathrm{mg} / 1$ \\
\hline Nitrate $\mathrm{NO}_{3}$ & 8.3 & 3.5 & 2.6 & 1.4 & 1.8 & 0.88 & 3.96 & 45 & $\mathrm{mg} / \mathrm{l}$ \\
\hline Nitrite NO2 & --- & 0.001 & 0.001 & 0.001 & 0.001 & 0.023 & 0.006 & 0.1 & $\mathrm{mg} / \mathrm{l}$ \\
\hline Sodium $\mathrm{Na}^{+}$ & 57 & 26.7 & 32 & 23 & 36.6 & 40.64 & 50.9 & 200 & $\mathrm{mg} / \mathrm{l}$ \\
\hline Fluoride $\mathrm{F}$ & 0.85 & 0.001 & 0.00 & 0.00 & 0.00 & 0.01 & 0.0 & 1.5 & $\mathrm{mg} / \mathrm{l}$ \\
\hline Iron $\mathrm{Fe}$ & 0.04 & 0.00 & 0.00 & 0.00 & 0.01 & 0.0 & 0.1 & 0.3 & $\mathrm{mg} / \mathrm{l}$ \\
\hline Manganese $\mathrm{Mn}+$ & --- & 0.2 & 0.1 & 0.7 & 0.2 & 0.0 & 0.0 & 0.1 & $\mathrm{mg} / \mathrm{l}$ \\
\hline
\end{tabular}

Table 3: Boreholes water analysis result specifying starting date for first sign of water contamination with non-fecal coliforms (NWSA-Wadi Hadramout).

\begin{tabular}{|c|c|c|}
\hline Borehole No. & $\begin{array}{c}\text { Date of start } \\
\text { of contamination }\end{array}$ & Sign of contamination after analysis \\
\hline 1 & $28 / 5 / 1997$ & Present \\
\hline 2 & $28 / 5 / 1997$ & Present \\
\hline 3 & $28 / 6 / 1998$ & 6 colonies \\
\hline 4 & $25 / 5 / 1997$ & Present \\
\hline 5 & $28 / 6 / 1998$ & 14 colonies \\
\hline 6 & $21 / 9 / 1998$ & 3 colonies \\
\hline 7 & $21 / 9 / 1998$ & 5 colonies \\
\hline
\end{tabular}

Boreholes were disinfected by chlorine solution at different intervals and repeatedly. Most of the boreholes gave a positive response to this method, except borehole No. 4 as shown in Table 4 . 


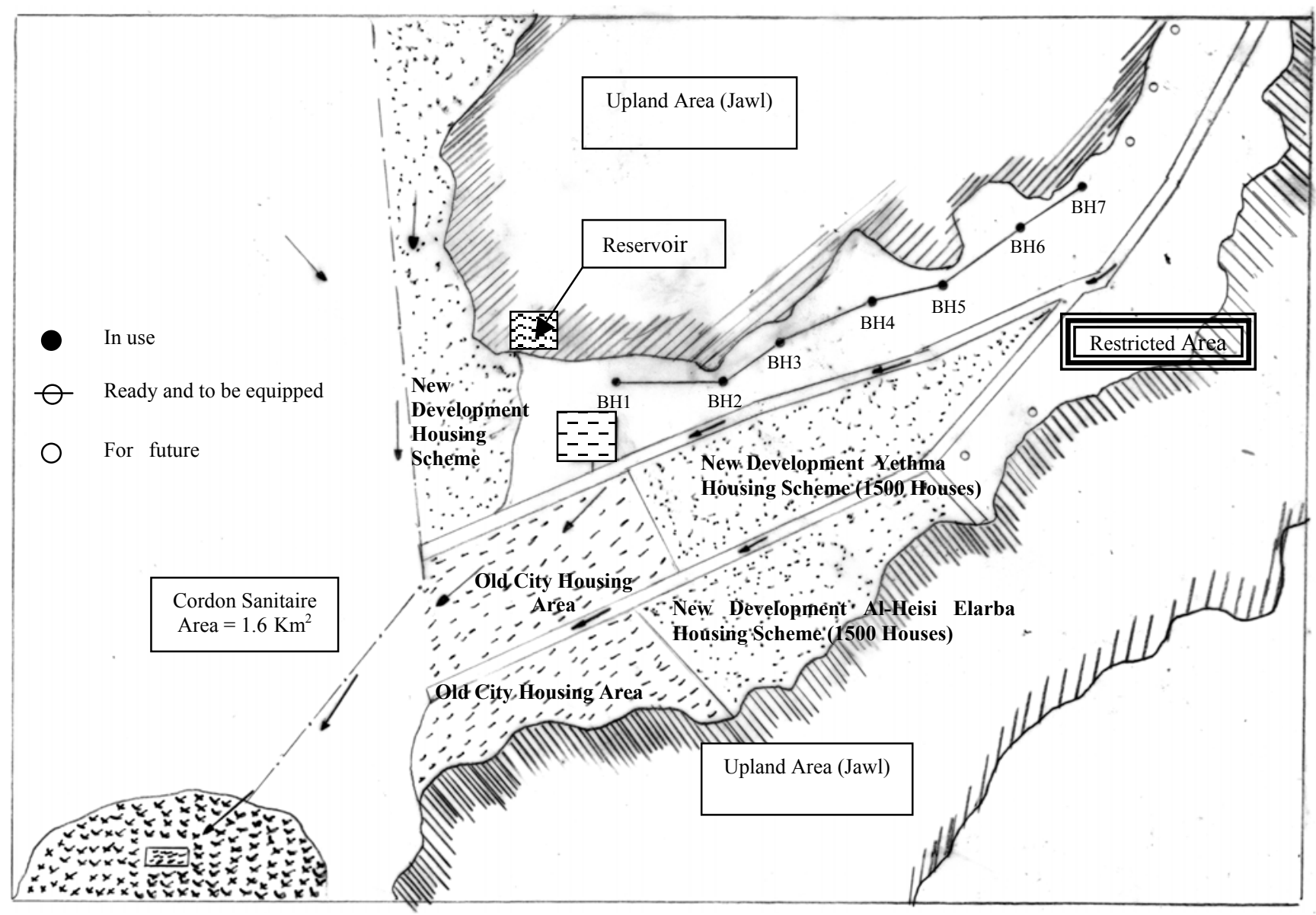

Figure 1. Actual wellfield protection zone (cordon sanitaire) for Seiyun.

It should be noted that the results given in Tables 3 and 4 are subject to the following remarks:

(a) Results for typical coliform are given in M.P.N. for colonies range from 20 to 200, and for above 200 they are referred as TNTC (too numerous to count), (M.G.Ondrus) and noted in the above tables by the term present.

(b) Table 4 results were taken after chlorination process and after closing the well for 36 hours.

(c) During sampling and analyzing there was no sign of residual chlorine present.

By repeating the chlorine disinfection, all the boreholes became satisfactory and water quality was within the acceptable standards. From monitoring and studies, it can be noticed that the response to the disinfection process for the boreholes takes a longer time than the earlier one. This is an indication that the contamination is progressing and needs to be carefully monitored and controlled. Consequently, continuous monitoring for the boreholes contamination is performed and necessary actions are taken by the authority.

\section{Engineering Options to Stop Contamination Threat in Seiyun Wellfield}

Chemical and bacteriological analyses carried out regularly by NWSA-Seiyun, showed that the quality of water is still within the acceptable standards except in some boreholes; mainly borehole No.4 which shows the starting of pollution with non-faecal califorms.The main reason behind this pollution is thought to be the new housing development. The new housing development closer to the wellfield presents a threat to the water quality on the long run. Therefore, the wellfield should be protected against this threat. Studies (Dar Al-Handasah) have been carried out and three engineering sanitary options are identified, presented and discussed. 
Table 4: Bacteriological examination results for borehole No.4 taken at NWSA Wadi Hadramout Branch-Seiyun for the period October-November 1999 (NWSA-Wadi Hadramout).

\begin{tabular}{|c|c|c|c|c|c|c|}
\hline Date Collected & $\begin{array}{c}\text { Hour } \\
\text { Collected }\end{array}$ & Temp. ${ }^{\circ} \mathrm{C}$ & $\begin{array}{c}\text { Date of Data } \\
\text { Analysis }\end{array}$ & $\begin{array}{c}\text { Time of } \\
\text { analysis }\end{array}$ & $\begin{array}{l}\text { M.P.N.T. } \\
\text { coliform }\end{array}$ & $\begin{array}{c}\text { Conductivity } \\
\boldsymbol{\mu S} / \mathbf{c m}\end{array}$ \\
\hline $6-10-98$ & 36 & 36 & $6-10-98$ & $12: 17$ & Present & 735 \\
\hline $11-10-98$ & 35 & 35 & $11-10-98$ & $11: 38$ & Present & 770 \\
\hline $17-10-98$ & 35 & 35 & $17-10-98$ & $12: 17$ & $(5)$ & 770 \\
\hline $22-10-98$ & 34 & 34 & $22-10-98$ & $12: 17$ & Present & 770 \\
\hline $26-10-98$ & 35 & 35 & $26-10-98$ & $12: 17$ & $(5)$ & 770 \\
\hline $7-11-98$ & 34 & 34 & $7-11-98$ & $12: 17$ & Present & 759 \\
\hline $15-11-98$ & 35 & 35 & $15-11-98$ & $12: 17$ & $(2)$ & 770 \\
\hline $23-11-98$ & 34 & 34 & $23-11-98$ & $12: 17$ & Present & 762 \\
\hline
\end{tabular}

\section{Option 1: Do Minimum Option (DMO)}

This option is the first step to reduce the contamination risk. It represents adopting watertight septic tanks to replace the existing soak pits for the localities close to the wellfield indicated in Figure 1. NWSA should take responsibility for the technical, management and service aspects of this option. Unfortunately, this option has numerous disadvantages related to already constructed septic tanks and some logistic matters.

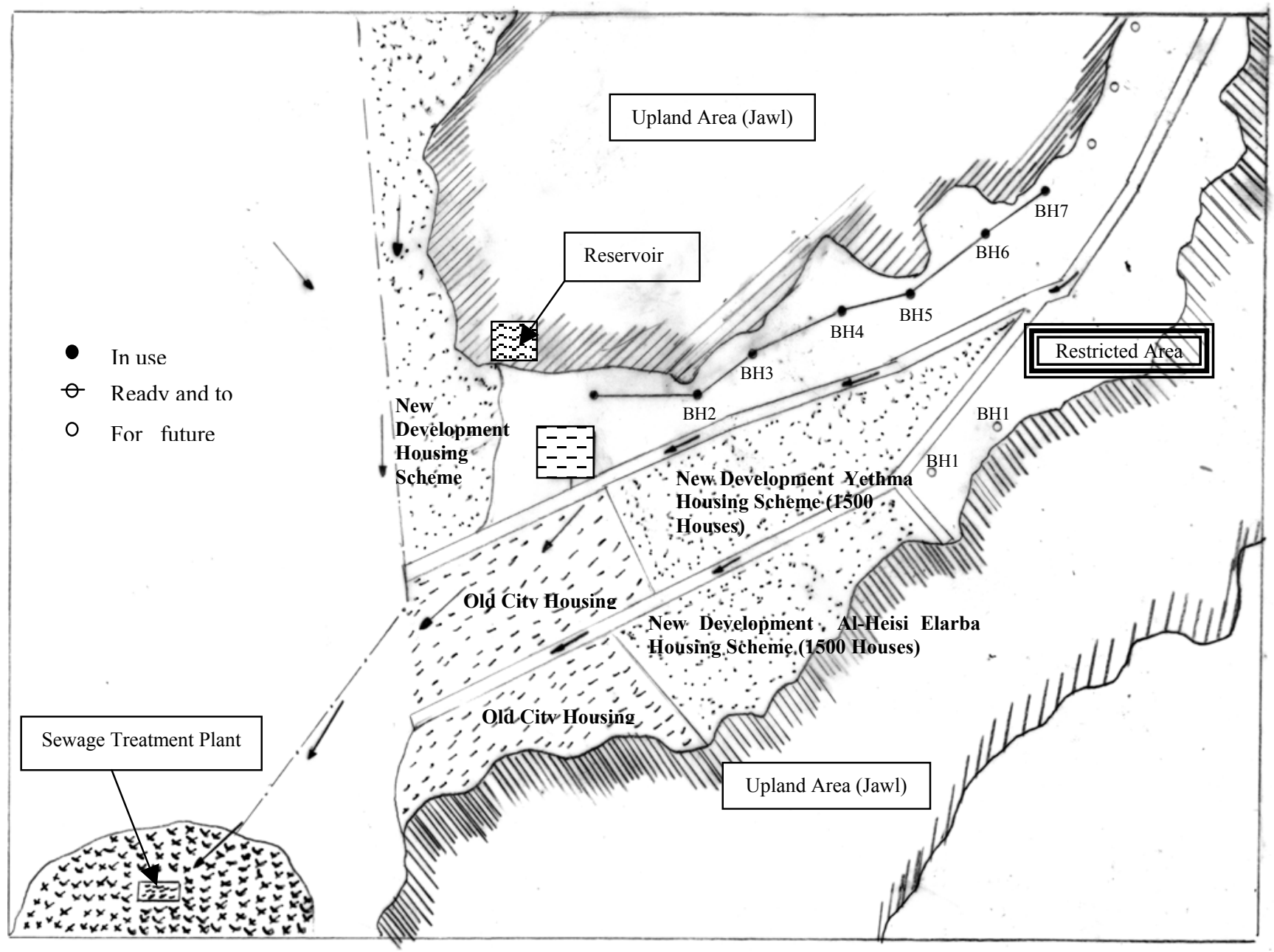

Figure 2. Proposed skelton sewage network for Seiyun. 


\section{Option 2: Cordon Sanitaire}

The Cordon Sanitaire Option (CSO) consists of creating a sanitized area surrounding the wellfield for a distance of at least $250 \mathrm{~m}$ from the closest well and the replacement of the septic tanks of the new housing schemes by a sewerage collection network and a treatment plant as shown in Figure 2. Around $30 \%$ of the housing units of around 300 houses falling within the CSO would have to be demolished, as indicated in Figure 1. The protection of the water quality of the wellfield is assured by creating a sanitized zone around it as shown in Figure 2.

This option has several requirements such as design and construction of the localities sewerage network and controlling the septic tanks in Option 1 until a sewerage network is constructed. The package treatment plant could then be dismanteled and replaced once the sewerage treatment plant of the town is operational.

In this option there is a possibility for reusing the effluent of the package treatment plant for the nearby Agricultural Research Center and for use in the cultivated land.

\section{Option 3: Wellfield Protection and Septic Tanks Management}

This option is in fact a combination of Options 1 and 2 above, constituting the DMO and CSO in which the establishment of a protection area i.e. erecting a surrounding fence at a distance of 250 $\mathrm{m}$ from closest well. In addition to the protection area, the protection wellfield zone is to be widenend up to $2500 \mathrm{~m}$. There must be a complete drainage system for the housing, industry, hospitals etc and pesticide and fertilizer applications should be limited. Industrial, animal husbandry and storage of hazardous chemicals will not be allowed. Figure 2 shows the extent of the $2500 \mathrm{~m}$ radius restriction area.

The requirement of this Option then would be:

- Controlling septic tanks as in Option 1 above for a short term until the sewerage network is constructed.

- Undertake the master plan study to trace the sewerage skeleton network and identify the proper site for the treatment plant and the impact of the plant on the airport runway. Then, design and construct the complete sewerage system.

\section{Brief Discussion of Options and Recommendations}

- The long-term sustainability of the DMO is questionable as it depends on some requirements that are not possible to achieve.

- The Wellfield Protection And Septic tank Management Option represent an improvement on the DMO. Although relatively more expensive, it remains affordable and rapidly implementable. But its feasibility depends on NWSA's capability. Nevertheless, this option is the safer as it would be hazardous to wait for the soil or water to become polluted before action is taken.

- The long term option (Option 3) has the advantage that the population will not be exposed to a health risk or odour nuisance since the treatment plant will not be located in the vicinity of the residential area.

Hence, the long-term option is recommended when the necessary funds for implementation become available.

\section{Cost Estimate for the Proposed Option}

The housing development areas concerned by the proposed priority sewage collection network are Yethma and Al-hisi-El-Arbaa housing schemes as shown in Figures 1 and 2. Their ultimate 
population capacity is estimated as 7,020 and 12,100 respectively. Their area would correspond to 40 ha and 69 ha.

The construction cost of the sewage collection network and the main conveyers has been estimated using the following rates (M.G. Ondrus):

1. Collection network, including manholes

US $\$ 25,000 /$ ha

2. Main conveyors, including manholes and lift station

US $\$ 15,000 /$ ha

3. Service connections, including demolition of existing

percolation pits, connection pipes and inspection chambers US $\$ 12,000 /$ ha

Based on an estimated generated sewage flow of $2100 \mathrm{~m}^{3} /$ day, and oxidation ditch type of treatment with an effluent quality of 20/30, the cost of the treatment plant is estimated as 1.5 million US dollars. The total add up initial investment and operation and maintenanace millions cost is given in Table 5 .

Table 5: Investment cost (Dar Al-Handasah),(MILLIONS US Dollars).

\begin{tabular}{|c|c|}
\hline Item & Cost \\
\hline Network & 2.726 \\
\hline Conveyance & 1.635 \\
\hline Service Connections & 1.308 \\
\hline Treatment Plant & 1.500 \\
\hline Sub Total & $\mathbf{7 . 2 0 0}$ \\
\hline Operation and maintenance Cost & .6145 \\
\hline Total & 7.814 \\
\hline
\end{tabular}

\section{Steps and Actions Taken by NWSA'S}

- Continuous monitoring of water quality at wellfield and at different points in the water distribution network.

- Regular samples of water are taken ,chemical and biological analysis are done.

- Immediate chlorine disinfection is done for water wells that show any biological pollution.

- Continuous consultation with consultants in case of any water contamination.

- The problem of water pollution have been reported to the higher authorities of NWRA and different funding agencies for funding the project of wellfields protection as given in the different options.

- Response for funding the wellfield protection and Seiyun Sanitary System is positive and being negotiated with the higher authorities.

\section{References}

DAR AL-HANDASAH, TARIM and SEIYUN ENVIRONMENTAL IMPACT STUDY, NWSAWadi Hadramout Branch, Seiyun - Republic of Yemen, 2.

KINGDOM OF NETHERLANDS, DIRECTORATE GENERAL DEVELOPMENT COOPERATION. INSTITUTIONAL STRENGTHENING, Five Years NWSA Branches Preparation Phase, Final Report February, 1999.

ONDRUS, M.G., 1980. Laboratory Experiments in Environmental Chemistry,Wuerz Publishing Ltd,Winnipeg, Canada.

NWSA-WADI HADRAMOUT BRANCH, Seiyun - Republic of Yemen, Internal Interim Reports.

Received 4 March 2000

Accepted 1 June 2000 